\title{
A NOTE ON SMALL BODIES OF ECLOGITE AS INCLUSIONS IN HIGH GRADE GNEISSES NORTH OF POUSO ALEGRE, MINAS GERAIS
}

\author{
ASIT CHOUDHURI*, ALBERTO PIO FIORI*, ANDREAS A.M. WINTERS* \\ JORGE S. BETTENCOURT* and JOSE E. RODRIGUES**
}

\begin{abstract}
In the area north of Pouso Alegre, Minas Gerais; small eclogite bodies occur included in high grade anatectic gneisses and are briefly described in this preliminary note. The eclogite consists of garnet, clinopyroxene - plagioclase symplectite and hornblende; the symplectitic pyroxene - plagioclase intergrowth is typical of eclogites from gneiss migmatite terrains and results from exsolution of plagioclase components from the original omphacite. The enclosing gneissic country rocks are garnet - biotite gneisses with newly formed sillimanite and remnants of kyanite. From field and petrographic evidence it is provisionally interpreted that the eclogites formed by dehydration of pre-existing metamorphosed basic rocks, such as amphibolites, during high pressure anatexis of the gneisses.
\end{abstract}

RESUMO Nesta nota preliminar são descritos pequenos corpos de eclogitos que ocorrem na região norte de Pouso Alegre (MG), como inclusões em gnaisses anatexíticos de alto grau de metamorfismo. Os eclogitos são constituídos por granada, simplectitos de clinopiroxênio - plagioclásio e hornblenda. Os intercrescimentos simplectíticos de piroxênio - plagioclásio são típicos de eclogitos que ocorrem em áreas gnáissicas - migmatíticas e resultam de exsolução dos componentes de plagioclásio a partir de onfacita original. As rochas gnáissicas regionais e hospedeiras dos eclogitos, são granada - biotita gnaisses que exibem neoformação de silimanita e remanentes de cianita. Os dados de campo e evidências petrográficas permitem inferir, em caráter preliminar, que os eclogitos se formaram através de desidratação de rochas básicas pré-existentes, tais como anfibolitos, durante a anatexia dos gnaisses em regime de alta pressão.

INTRODUCTION Coleman et al. (1965) have classified eclogites into three groups according to their mineralogy, mode of occurrence and rock association in the field. On this basis we have eclogites which occur as inclusions in kimberlites, basalts and ultrabasic rocks; those which occur in high grade migmatite-gneiss terrains, and a third group of eclogites which occur in the form of lenses and layers within rocks metamorphosed in the blueschist facies. These eclogite types, corresponding to groups A, B and C, respectively, have characteristic mineralogies inasmuch as those of group $A$ which consist almost entirely of omphacite pyroxene and garnet, those of group B may have in addition primary hornblende and/or zoisite, while group $\mathrm{C}$ eclogites have primary glaucophane and epidote (Winkler, 1976). With regard to their controversial origin, i.e., whether they originated in the upper mantle or in the crust, recent investigators (Bryhni et al., 1970, Griffin and Raheim, 1973) have presented convincing evidence for the formation of the eclogites in the Precambrian gneissic terrains of Norway by metamorphism of supracrustral rocks.

Eclogites typically associated with gneisses and migmatites present symplectitic intergrowth of clinopyroxene and plagioclase as a result of exsolution of plagioclase

\footnotetext{
* Departamento de Mineralogia e Recursos Minerais - UNESP - Rio Claro

** Escola de Engenharia de São Carlos - USP - São Carlos
} 
from the original omphacite; the cause of the exsolution has been sought in the process of heating and/ or uplift of the eclogites to shallower crustal levels (Mysen and Heier, 1972; Raheim and Green, 1975); in other words, an increase in temperature or a pressure drop can bring about the exsolution of plagioclase from the omphacite. Small bodies of eclogite enclosed in high grade gneisses, similar to the occurrences in Norway, have been found in southern Minas Gerais, and are briefly described in this note; further studies are being carried out. The other known occurrences of eclogite are in Colombia (Green et al., 1968) and in Venezuela (Morgan, 1970). In the first example the rocks occur as boulders in Mid-Tertiary conglomerates thought to be derived from a Mesozoic metamorphic sequence. In the second case the eclogites occur associated with garnet amphibolites in the form of conformable lenses in the metamorphosed Mesozoic-Lower Cretaceous rocks of the Caracas Group.

REGIONAL SETTING Southern Minas Gerais has been extensively mapped by Ebert (1968, and verb. comm), and is presently being mapped in greater detail. The gneissic-migmatitic terrain consists of older gneisses, anatectic gneisses and possible migmatites of the Trans-Amazonic orogenic cycle, and includes charnockites, granulites and garnet-sillimanite gneisses. These rocks were later invaded by granitic rocks and migmatized during the Brazilian Cycle, which resulted in retrogression of some of the granulite facies rocks (Wernick and Penalva, 1974).

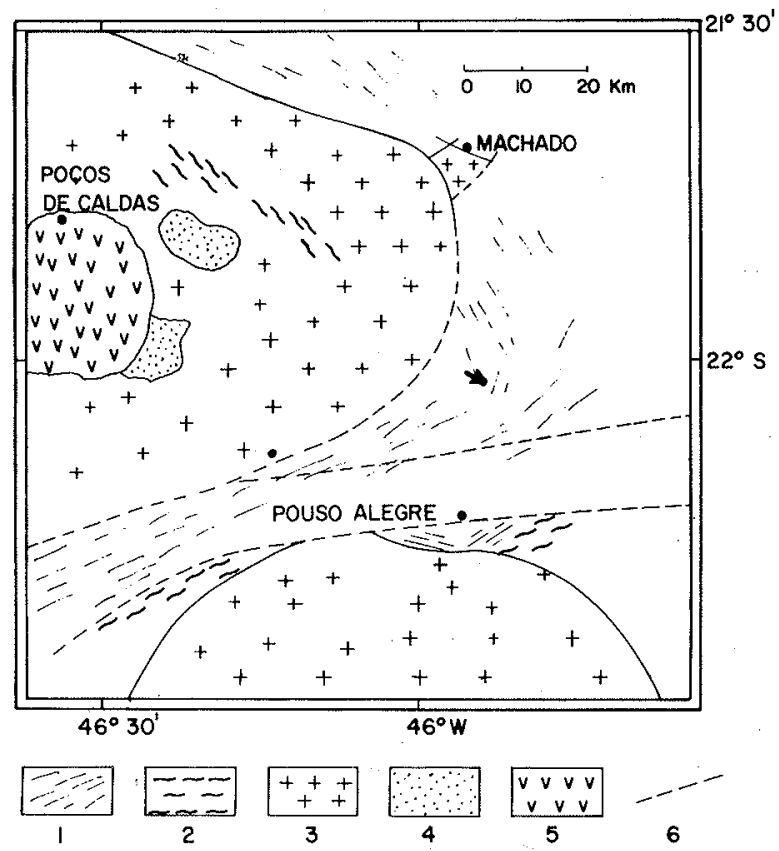

Figure 1 - Sketch map of the area north of Pouso Alegre, Minas Gerais (adapted from geological maps of the Projects Caldas I, Caldas II, Ouro Fino and Pouso Alegre of the Instituto de Geociências, Rio Claro, SP. with permission from D.N.P.M.). Main geological units area as follows: 1) gneisses of the Trans-Amazonic Cycle, 2) charnockites and granulites, 3) Migmatites of the Brazilian Cycle, 4) syenites, end of the Brazilian Cycle, 5) Tertiary alkaline complex, 6) regional faults. Arrow indicates location of eclogite occurrence 
In the area north of Pouso Alegre, M.G. (Fig. 1), small eclogite bodies occur as inclusions in anatectic gneisses, which are locally garnet-rich, and which appear to have been uplifted along faults and juxtaposed against gneisses of apparently lower metamorphic grade according to a provisional model envisaged in the field by one of us (J.E.R.). Field observations also suggest that the gneisses must have reached a high degree of mobilization in order to enclose so completely these eclogites, just as they also enclose large blocks or nodules of other metamorphosed basic rocks in neighbouring areas.

PETROGRAPHY The eclogite collected by us is a medium-grained, granular dark greenish-grey rock very rich in garnet. In hand-specimens the orange-pink garnets vary from 1.0 to $1.5 \mathrm{~mm}$ in diameter and are rimmed by dark green amphibole separated in a matrix of pale green pyroxene; in some of them there is a perceptible but faint foliation due to the orientation of the amphibole. At places the eclogites are cut by thin quartz veins, probably derived from the enclosing gneisses. In thin section the texture is granoblastic with kelyphitic rims of hornblende separating clinopyroxene symplectite from the garnets (Fig. 2).

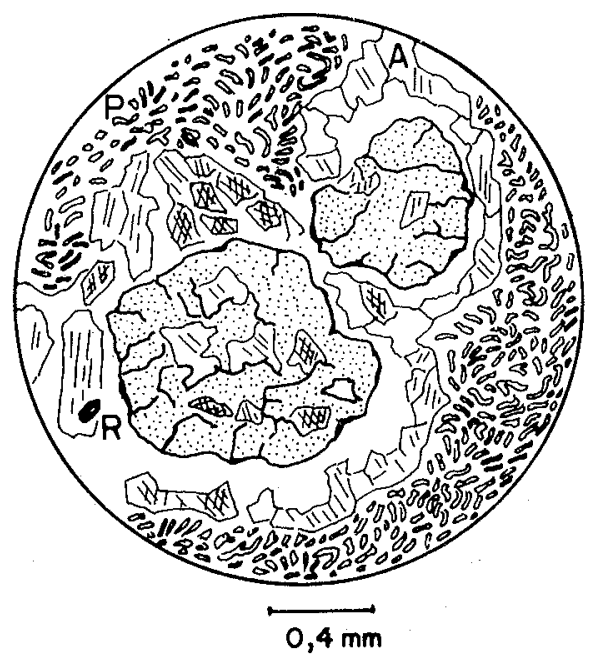

Figure 2 - Porphyroblasts of garnet about 1.0 to $1,5 \mathrm{~mm}$ in diameter rimmed by plagioclase and hornblende, and set in a matrix of clinopyroxeneplagioclase symplectite. $\mathrm{A}=$ amphibole, $\mathrm{P}=$ pyroxene, $\mathrm{R}=$ rutile

Under the microscope garnets are pale pink and subhedral, often fractured and disrupted, with inclusions of quartz, clinopyroxene, hornblende and rutile. Hornblende is generally granular or poikiloblastic, forming rims around garnets and occasionally around pyroxene; most of the hormblendes are very pale olivegreen to diffuse pale clove-brown and may be a magnesium-rich variety. The pale brown coloration is often associated with opaque minerals in the thin section and may be due to local oxidation of the hornblende.

The clinopyroxene is pale green and anhedral and most of it forms abundant symplectite with vermicular plagioclase. The grain outlines of individual pyroxenes are discernible under crossed polarizers. The pyroxene occurs in two forms, one of which is subhedral and granular and the other the more abundant symplectitic variety. Pyroxene-plagioclase symplectite is also seen as inclusions in some of the garnets. The pyroxenes are similar to those described by Mysen (1972). The composi- 
tion of the larger polygonal, incipiently twinned plagioclase which forms borders between the garnet and hornblende, was estimated optically by the extinction angle method. The plagioclases are optically positive with moderate $2 \mathrm{~V}$, and have refractive indices equal to or somewhat less than the Canada Balsam of the thin sections.

These properties combined with the extinction angle give an estimated composition of about $\mathrm{An}_{8}$. The fine vermicular plagioclases of the symplectite could not be estimated as they are untwinned; however, their $2 \mathrm{~V}$ and refractive index are similar to the larger grains, and are therefore probably also in the albite range. Rutile is an accessory mineral and occurs as subhedral to prismatic grains which are rarely twinned and are of dark yellow-brown color and high relief. Petrographic examination of the country rocks show that they are quartz-plagioclase gneisses with subhedral garnet, colorless to light-brown biotite (with large pleochroic haloes around zircon inclusions), fine prismatic sillimanite and a few grains of kyanite.

The sillimanite appears to form from the biotite which has rims of opaque minerals along the borders. It is thus possible that biotite is breaking down incipiently under high temperature and oxidizing conditions, and contributing aluminium towards sillimanite formation. The problem of the apparent origin of sillimanite in this manner has been discussed by Chinner (1961).

POSSIBLE PHYSICAL CONDITIONS FOR ECLOGITE FORMATION At high pressures diopside is capable of dissolving the albite and anorthite components of plagioclase which are held in solid solution as jadeite, $\mathrm{NaAlSi}_{2} \mathrm{O}_{6}$, and $\mathrm{Ca}$ Tschermak's molecule, $\mathrm{CaAl}_{2} \mathrm{SiO}_{6}$ respectively. The resulting pyroxene is the omphacite of eclogites. With increasing pressure the field of clinopyroxene + plagioclase + quartz thus gives way to omphacite + quartz, whereby the percentage of jadeite component in clinopyroxene also increases with pressure (Kushiro, 1969).

The omphacites of eclogites from gneissic terrains often break down to a diopside (or sodic augite) + plagioclase symplectite as a result of either decrease in pressure and/or increase in temperature. Symplectitization as discussed by Mysen and Griffin (1973) requires that the omphacite either breaks down by the addition of quartz or the oxidation of $\mathrm{Fe}^{2+}$ to $\mathrm{Fe}^{3+}$. For the pyroxene in the eclogite from Minas Gerais the high silica activity deriving from the enclosing quartz-rich gneisses may have facilitated the stoichiometric breakdown of the original omphacite, assisted by dynamic physical conditions such as uplift or isothermal drop in pressure; possible and approximate isothermal conditions are presumed due to the anatectic nature of the enclosing gneisses, transition from the kyanite to the sillimanite fields (refer Fig. 3) and uplift to their present position where these gneisses abut against lower grade banded gneisses.

As to the origin of the eclogites themselves - even if these rocks formed by strong dehydration under anatectic conditions in which water pressure is much less than the total or load pressure, fairly high pressures would be necessary to stabilize the mineral paragenesis of these rocks. Fig. 3 illustrates the pressures required for the transition of basic rocks of olivine-tholeiite or quartz-tholeiite composition to garnet granulite and eclogite (Green and Ringwood, 1967, 1972). An indication of high pressure comes from the gneisses in which the eclogite occurs; these gneisses contain newly formed sillimanite and remnants of kyanite, so that high pressure anatexis occurred traversing the stability field of kyanite before the formation of sillimanite. 


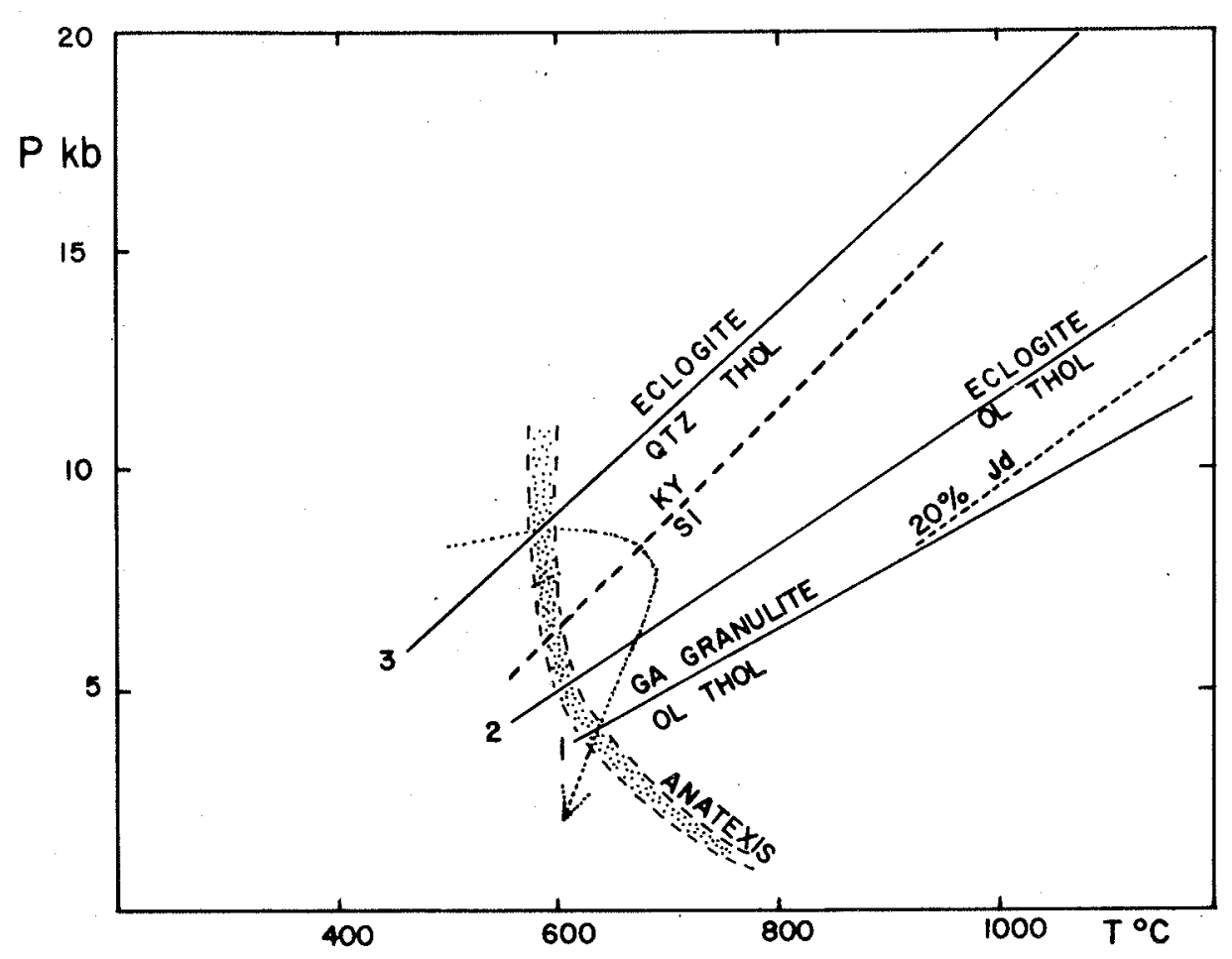

Figure $3-\mathbf{P}, \mathbf{T}$ conditions for gabbro-garnet granulite-eclogite transition after Green and Ringwood (1972); the stability fields of kyanite and sillimanite, and the beginning of anatexis in quartzo-feldspathic rocks are from Winkler (1976), and the line for $20 \%$ jadeite in omphacite is from Kushiro (1969). Dotted line with arrow indicates highly conjectural path of metamorphism of the eclogite from Minas Gerais. (OL THOL = olivine tholeiite, QTZ $\mathrm{THOL}=$ quartz tholeiite, $\mathrm{GA}=$ garnet, $\mathrm{KY}=$ kyanite, $\mathrm{SI}=$ sillimanite $)$

The formation of hornblende in the rocks requires an access of water subsequent to symplectite formation, and the water of the anatectic gneiss melt may have been made available again, at least in part, after its consolidation had been achieved. The sequence of events, therefore, might have been: dehydration of amphibolites to form eclogites during high pressure anatexis followed by uplift and partial rehydration. The conjectured path of events of changing physical conditions is shown in Fig. 3 (Various P,T paths for other eclogites have been proposed by Ráhein and Green, 1975).

Further indication of high pressure of formation for the rocks is given by quartz inclusions in the garnets - i.é., these rocks might have been originally quartz tholeiitic, in which case load pressures may have been in the region of 8 to $10 \mathrm{~kb}$ for their transformation to eclogite; this would be the range of physical conditions necessary for the kyanite-sillimanite transition as well as widespread anatexis in the gneisses, coupled with the fact that the enclosed basic rocks would attain the eclogite stability field as indicated in Fig. 3. Elsewhere in this area where the eclogite bodies occur there are within a radius of about $50 \mathrm{~km}$ migmatitic hornblende-biotite gneisses which have disrupted mafic and ultramafic rocks and transformed them to 
pyroxene granulites, and in the process typical schollen and agmatitic structures have resulted. Applying these observations it may be concluded that the eclogites probably also represent disrupted and metamorphosed basic bodies such as the amphibolites which commonly occur with the gneisses of the region.

Acknowledgment We are grateful to Prof. Dr. Heinz Ebert for lively discussions in the field and for his assistance in the recognition of the eclogite bodies dealt with in this note. We are also grateful to the Departamento Nacional de Produção Mineral for financial support of field work and geological mapping in Minas Gerais.

\section{REFERENCES}

BRYHNI, I.; FYFE, W.S.; GREEN, D.H.; and HEIER, K.S. - 1970 - On the occurrence of eclogite in western Norway. Contr. Mineral and Petrol. 26: 12-19.

CHINNER, G.A. - 1961 - The origin of sillimanite in Glen Clova, Angus. Jour. of Petro logy, 2: $312-323$.

COLEMAN, R.G.; LEE, D.E.; BEATTY, L.B. and BRANNOCK, W.W. - 1965 - Eclogites and eclogites; their differences and similarites. Bull. Geol. Soc. Am. 7.6: 483-508.

EBERT, H. - 1968 - Ocorrência da facies granulítica no sul de Minas Gerais e em áreas adjacentes em dependência da estrutura orogênica: hipóteses sobre a sua origem. An. Acad. Bras. Ciênc. 40 (supl.) 215-229.

GREEN, D.H.; LOCKWOOD, J.P. and KISS, E. - 1968 - Eclogite and almandinejadeite-quartz rock from the Guajira Peninsula, Colombia, South America. Am. Mineral. 53: 1320-1335.

GREEN, D.H. and RINGWOOD, A.E. - 1967 - An experimental investigation of the gabbro to eclogite transformation and its petrological implications. Geochim. Cosmochim. Acta. 31: 767-833.

GREEN, D.H. and RINGWOOD, A.E. -- 1972 - A comparison of recent experimental data on the gabbro-garnet granulite-eclogite transitions. J. Geol. 80: 277-288.

GRIFFIN, W.L. and RAHEIM, A. - 1973 - Convergent metamorphism of eclogites and dolerites, Kristiansund area, Norway. Lithos 6: 21-40.

KUSHIRO, I. - 1969 - Clinopyroxene solid solutions formed by reactions between diopside and piagioclase at high pressures. Mineral Soc. Am. Spec. Pap. 2: 179-191.

MORGAN, B.A. - 1970 - Petrology and mineralogy of eclogite and garnet amphibolite from Puerto Cabello, Venezuela. Jour. Petrology 11: 101-145.

MYSEN, B.O. - 1972 - Five clinopyroxene in the Hareidland eclogite, western Norway, Contr. Mineral. and Petrol. 34: 315-325.

MYSEN, B. and GRIFFIN, W.L. - 1973 - Pyroxene stoichiometry and the breakdown of omphacite. Am. Mineral. 58: 60-63.

MYSEN, B.O. and HEIER, K.S. - 1972 - Petrogenesis of eclogites in highgrade metamorphic gneisses exemplified by the Hareidland eclogite, western Norway. Contr. Mineral and Petrol. 36: 73-94.

RAHEIM, A. and GREEN, D.H. - 1975 - P,T paths of natural eclogites during metamorphism - a record of subduction. Lithos 8: 317-328.

WERNICK, E. and PENALVA, F. - 1974 - Migmatização e feldspatização de charnockitos e granulitos no leste paulista e sul de Minas Gerais. An'. XXVIII Congr. Bras. Geol. 5: 155-160, Porto Alegre.

WINKLER, H.G.F. - 1976 - Petrogenesis of metamorphic rocks. - Springer Verlag. New York: 4 a ed 